\title{
Probabilistic Seismic Hazard Analysis for Offshore Structures in the Santa Barbara Channel Phase 2 Report
}

\author{
W. Foxall
}

J. Savy

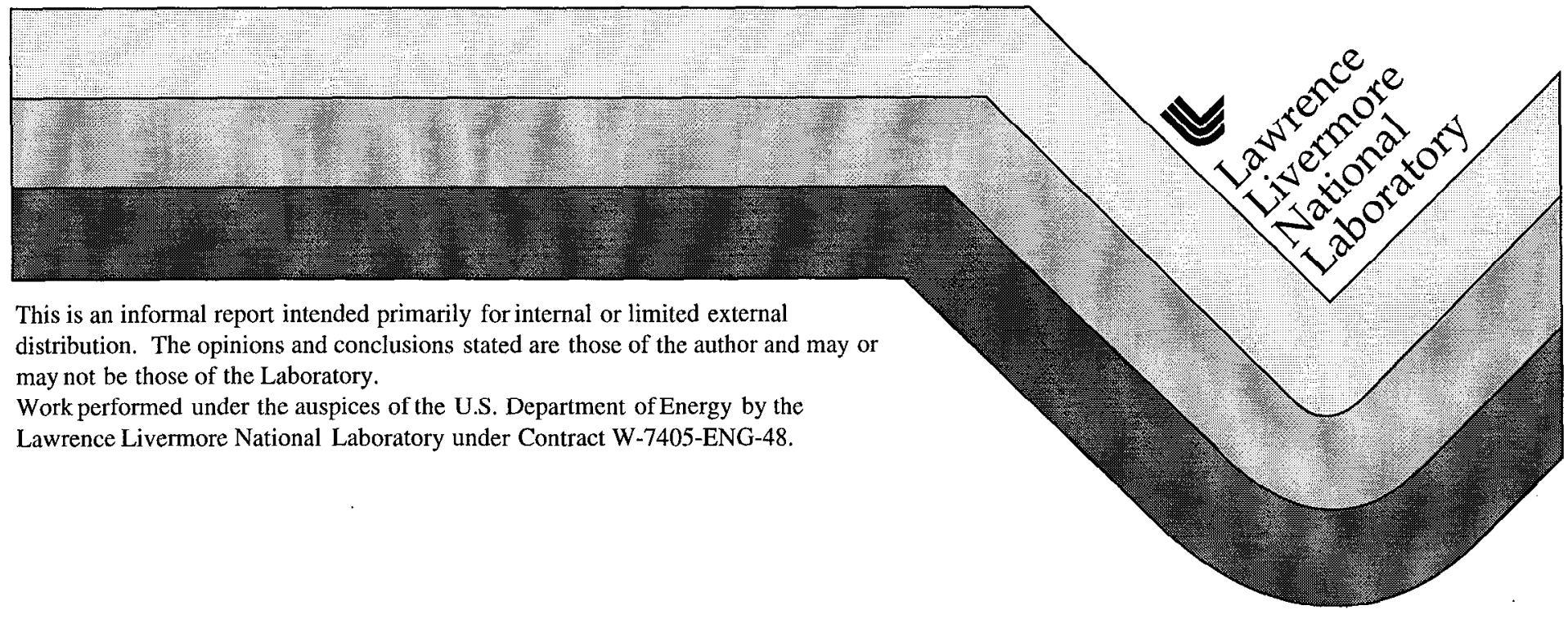




\section{DISCLAIMER}

This document was prepared as an acccount of work sponsored by an agency of the United States Government. Neither the United States Government nor the University of California nor any of their employees, makes any wartanty, express or implied, or assumes any legal liability or responsibility for the accuracy, completeness, or usefulness of any information, apparatus, product, or process disclosed, or represents that its use would not infringe privately own rights. Reference herein to any specific commercial products, process, or service by trade name, trademark, manufacturer, or otherwise, does not necessarily constitute or imply its endorsement, recommendation, or favoring by the United States Govermment or the University of California. The views and opinions of authors expressed herein do not necessarily state or reflect those of the United States Government or the University of California, and shall not be used for advertising or product endorsement purposes.

This report has been reproduced directly from the best available copy.

A vailable to DOE and DOE contractors from the Office of Scientific and Technical Information P.O. Box 62, Oak Ridge, TN 37831

Prices available from (615) 576-8401, FIS 626-8401

Available to the public from the National Techrica! Information Service

U.S. Department of Commerce 5285 Port Royal Rd., Springfield, VA 22161 


\title{
PROBABILISTIC SEISMIC HAZARD ANALYSIS FOR OFFSHORE STRUCTURES IN THE SANTA BARBARA CHANNEL
}

PHASE 2 REPORT

\author{
Prepared by: \\ William Foxall and Jean Savy \\ Lawrence Livermore National Laboratory \\ 7000 East Avenue \\ Livermore CA 94550
}

\section{Project manager:}

Robert Murray

\section{Prepared for}

Minerals Management Service

Technology Assessment and Research Branch

381 Elden Street, MS 4700

Herndon, Virginia 


\title{
PROBABILISTIC SEISMIC HAZARD ANALYSIS FOR OFFSHORE STRUCTURES IN THE SANTA BARBARA CHANNEL
}

\author{
PHASE 2 REPORT
}

\section{INTRODUCTION}

This report summarizes progress through Phase 2 of the probabilistic seismic hazards analysis (PSHA) for the Santa Barbara Channel being carried out by the Lawrence Livermore National Laboratory (LLNL) for the Minerals Management Service (MMS) of the US Department of the Interior. The purpose of the PSHA is to provide a basis for development by MMS of regulations governing evaluation of applications to relicense existing oil platforms in federal waters within the Channel with respect to seismic loading. The final product of the analysis will be hazard maps of ground motion parameters at specified probability levels of exceedence. This report summarizes the characterization of local earthquake sources within the Channel and onshore areas of the Western.Transverse Ranges, development of a ground motion attenuation model for the region, and presents preliminary hazard results at three selected sites.

\section{SUMMARY OF PHASE 1 WORK}

In order to properly achieve the intended regulatory basis, the PSHA must incorporate the uncertainties in characterizing earthquake sources and in ground motion attenuation in the southern California region, and propagate those uncertainties through the analysis to provide estimates of the uncertainty in the hazard, in the form of mean estimates and other statistical parameters (Senior Seismic Hazard Analysis Committee, 1995). These uncertainties include both aleatory (random) uncertainties and epistemic uncertainities, which arise from the inability, through lack of knowledge, of our models of the Earth to describe its behavior perfectly. Therefore, the primary objective of Phase 1 of the project was to define and evaluate issues that introduce significant uncertainties into seismic hazard estimation in southern California in general (Working Group on California Earthquake Probabilities, 1995), and to assess in detail the impact of these issues on seismic hazard in the Channel. As is generally the case in PSHA, the evaluation focused largely on sources of epistemic uncertainty. The major issues affecting earthquake source characterization in this region stem from the fundamentally 
different models of tectonic deformation, "thin-skinned" or "thick-skinned", that have been proposed based upon alternative interpretations of the available data. These issues are currently the focus of intense debate. The main issues affecting ground motion attenuation under the Channel are the absence of a strong motion data base for offshore environments, the effects of sedimentary basins and wedges, and the effects of the water column and saturated soils. These issues and their impact on seismic hazard estimation in the Channel are discussed in detail in the draft Phase 1 report, dated April 27, 1996. Based upon the preliminary characterization of earthquake sources included in the Phase I report, we developed three preliminary alternative earthquake source maps for the Western Transverse Ranges, which incorporated the geometries and slip rate estimates of the potentially significant faults that form part of each of the proposed alternative tectonic models.

Phase 1 culminated in a workshop at Stanford University on August 16-17, 1995. in which scientists currently working on key aspects of the tectonics of the Western Transverse Ranges and on ground motion estimation offshore participated (see Appendix). The workshop served as a forum both for dissemination of current data and interpretations and to elicit expert opinion in finalizing our earthquake source and ground motion models. Specific objectives were: (1) To ensure that we had considered all available data and current tectonic interpretations in framing the major issues and in identifying significant earthquake sources; (2) to make a comparative evaluation of the evidence supporting the competing tectonic models and specific sources as a basis for weighting the alternatives; (3) using our preliminary source maps as "straw men", to develop the basis for a set of maps that fully captures the alternative tectonic hypotheses and accurately represents significant potential sources: and (4) to refine our preliminary ground motion attenuation model and ensure that it is the most suitable form for use offshore. These objectives were successfully achieved during the workshop.

\section{PHASE 2}

\section{Earthquake Source Models}

The results of the workshop, together with comments on the Phase 1 draft report received from several reviewers, indicated that the major tectonic interpretations and their variations can be represented by two basic, or "core", earthquake source models corresponding to the thick- (Model 1) and thin-skinned (Model 2) interpretations. Within 
each of these a considerable number of alternative fault geometries are permitted by the data and need to be included to capture adequately the epistemic uncertainty in source characterization.

Having identified the sources comprising each of the core models, detailed characterization of the models involved: (1) Defining the alternative geometries. These alternatives can include ranges of fault dips, possible fault segmentation schemes, and multi-segment rupture scenarios. One source of complexity is the inter-dependence of the down-dip geometries of several of the non-vertical faults, such that alternative geometries for one fault also require alternatives for neighboring faults. Combinations of all the possible fault geometries lead to a large number of alternative source maps for both Models 1 and 2; (2) estimating probability distributions for fault slip rates from the available data; (3) estimating probability distributions for characteristic moment magnitudes $\left(\mathrm{M}_{\mathrm{w}}\right)$ for each of the fault segments and segment combinations, based upon their fault areas. For this we used the area-moment magnitude $\left(\mathrm{M}_{\mathrm{w}}\right)$ relationship of Wells and Coppersmith (1994); and (4) the slip rates and maximum magnitudes were combined to estimate earthquake recurrence rate distributions for a range of magnitudes for each source employing the characteristic earthquake recurrence model of Youngs and Coppersmith (1985). The regional Gutenberg-Richter ' $b$ ' value of $0.75 \pm 0.5$ used to construct the recurrence relationships was estimated from the Caltech Western Transverse Ranges earthquake catalog for the period 1883-January, 1994 and for magnitudes $4.0 \leq \mathrm{M} \leq 6.7$.

In Phase 2 we completed the characterizations of the geometries of both Models 1 and 2, and digitized the maps. We have completed parameterization of the Model I sources and, using the composite ground motion attenuation model also developed during this phase (described in a later section), have computed initial estimates of the hazard resulting from Model 1 at three offshore sites. The preliminary results presented in this report, therefore, do not include the Model 2 sources.

\section{Model I}

Figures 1 is a map of the faults comprising Model 1. Depth sections through the model are shown in Figure 2. Model 1 is based upon the "thick-skinned" tectonic hypothesis proposed primarily by Yeats (1993) and Huftile and Yeats (1995, 1996) (see Phase 1 report). According to this hypothesis, which is based largely upon surface or 
near-surface observations of fault slip and upon geodetic data, active faults extend into the middle and lower crust at the relatively steep dips observed at shallow crustal depths. The model largely comprises surface faults, but also includes three blind reverse faults (Figure 1) - a blind extension of the Oak Ridge fault under the Santa Barbara Channel, a major blind thrust fault under the Ojai Valley and Topatopa Mountains, and the Northridge fault, the source of the $1994 \mathrm{M}_{W} 6.7$ Northridge earthquake. The Oak Ridge and Ojai blind thrusts have not been observed directly but are inferred from modeling of surface faulting and folding data. For this model, the blind Oak Ridge thrust in particular makes a large contribution to the hazard in the Channel. The Model 1 faults are described in the Phase I report. Additional information for some of the faults is summarized below. Fault parameters are given in Table 1, in which data references are identified.

Santa Ynez Fault: Segmentation of the Santa Ynez fault for this project is based upon more or less prominent geometrical irregularities in the fault trace. The South Branch segment certainly appears to be distinct (Figure 1), but it's relationship to the rest of the fault is not clear. The boundary between the Central and Eastern segments is the prominent offset in the fault trace north of Ventura (Figure 1). The dip of the fault is taken as $75^{\circ} \mathrm{S}$, based upon relatively precise microearthquake hypocenters near Lake Casitas recently reported by the US Bureau of Reclamation (draft report, 1996).

San Cayetano Fault: In the model of Huftile and Yeats $(1995,1996)$ north-south shortening localized at the northern boundary of the central Ventura Basin is partitioned between the western segment of the San Cayetano fault and the blind thrust hypothesized to underlay it (Figures 1-2) (see below).

Red Mountain Fault: The slip rate on the Red Mountain fault is constrained only within broad bounds, but appears to die out rapidly from the Channel coast towards the west. The eastern end of the fault is well defined both on- and off-shore, and is divided into two segments (East and Central) roughly at the coast. This segmentation was suggested by Huftile and Yeats (1995) based upon an apparent change in sub-surface geometry, but in our model is motivated chiefly as a means of accommodating the apparently rapid fall off in slip rate from east to west. The existence of the fault is not certain west of the Central segment. Two additional low slip rate segments, West and West (Figure 1), allow alternative definitions of the fault that extended to the west. The West and West segments exist only as contiguous combinations with the central or (east+central) 
segments: i.e. the allowed configurations that include these two scgments are; (central+west1), (central+west 1+west2), (east+central+west1), (east+central+west $1+$ west2). Configurations that include segment West can also be linked to the North Channel Slope fault.. The preferred dip configuration for the Red Mountain fault (and also the North Channel Slope fault below) is $65^{\circ}$ from the surface to a depth of approximately $12-13 \mathrm{~km}$ and $35^{\circ}$ below that. This is based on the Bureau of Reclamation microearthquake locations and on the apparent association of the 1978 Santa Barbara earthquake and its aftershocks with the Red Mountain-North Channel slope system.

North Channel Slope Fault: Recent interpretation of 3-D seismic data (Hornafius et al., 1995) and the apparent correlation with the 1978 Santa Barbara earthquake strengthen the case for the North Channel slope fault being a significant source in the NW Channel. Hornafius et al. interpret the fault in a thin-skinned context as rooting into a mid-crustal detachment. The slip rate on this fault estimated by Hornafius et al. is poorly constrained but appears to be relatively low, consistent with other observations in the NW Channel (Rockwell et al., 1992).

Ojai Blind Thrust: The geometry of and slip rate on the thrust are inferred from a balanced cross-section, (Huftile and Yeats, 1995) and are thus model dependent. The thrust is divided into east and west segments (G. Huftile, personal communication, 1995).

Santa Susana Fault: The Santa Susana fault is included in Model 1 because it is identified as the eastern continuation of the Red Mountain-San Cayetano fault system, at which rapid south-vergent shortening at the northern boundary of the Ventura Basin is localized (Huftile and Yeats, 1996) The geometry of the Santa Susana fault relative to the Northridge and San Gabriel faults is not clear. It's slip rate appears to be high, but is not well constrained (Huftile and Yeats, 1996).

Santa Monica Fault: In addition to a minimum dip-slip rate of about $0.6 \mathrm{~mm} / \mathrm{yr}$ (McGill, 1989; Jim Dolan, personal communication, 1996), the Santa Monica fault also has a poorly constrained minimum left-lateral rate of $\sim 0.1 \mathrm{~mm} / \mathrm{yr}$ (J. Dolan, personal communication, 1996), but the maximum left-lateral rate remains unconstrained.

Dume Fault: The Dume fault is observed to dip steeply to the north on seismic refraction profiles (Davis and Namson, 1994a) and is associated with a $400 \mathrm{~m}$ high 
seafloor scarp. Assuming that his fault was the source of the $1973 \mathrm{M}_{\mathrm{L}}$ Pt. Magu earthquake (see Phase 1 report), the mechanism of this event suggests a left-lateralreverse sense of slip. The slip rate, however, is essentially unconstrained, and is based on the suggestion ( $G$. Treiman, personal communication, 1996) that slip on the Palos Verdes fault is transferred across the Santa Monica shelf to the eastern end of the Dume fault. The kinematic viability of this suggestion remains to be verified.

Malibu Coast Fault: This fault is very poorly understood, and it's sense of slip and slip rate are essentially unconstrained. Interpretation of the role of this fault in transferring slip on the Hollywood-Santa Monica fault system westward depends to a large degree on interpretation of the Dume fault.

Blind Oak Ridge Thrust: In the model of Yeats et al. (1988) and Huftile and Yeats (1995), shortening on the onshore Oak Ridge fault is transferred to the Sisar decollement under the Oxnard Plain and eastern Channel (see Phase 1 report). South of the offshore Oak ridge trend, the Sisar decollement ramps down to the south as a blind western extension of the Oak Ridge fault. This hypothesized north-verging blind thrust makes an important contribution to the hazard in the Channel. The geometry of and slip on the thrust are inferred from balanced cross-sections and are therefore model dependent. The $30^{\circ}$ dip of the thrust is essentially unconstrained ( $\mathrm{G}$. Huftile, personal communication, 1995). Huftile and Yeats do not describe the geometry of the lateral transformation of the surface Oak Ridge fault into the blind thrust. To account for the apparent geometry of this transformation we have split the thrust into eastern and western segments, but the preferred source model combines these segments as a single rupture. Huftile and Yeats do not define the western end of the thrust, but R. Yeats (personal communication, 1996) suggests that the Sisar decollement extents as far as the Dos Cuadros field. To represent this uncertainty, we have defined a western segment of the blind Oak Ridge thrust (Figure 1) that can rupture only in concert with the central or east+central segments.

\section{Model 1 Fault Combinations : Event Trees}

Each possible combination of the alternative characterizations (geometry, including segmentation, and slip rate) of the individual sources forms one source map from which the hazard can be estimated. Alternative characterizations are represented by branches of an event tree, and a source map is compiled by working along a limb formed by connected branches. We assigned a subjective weight to each branch that expresses 
our degree of confidence both in the existence of that source and that this particular alternative characterization represents the process that generates earthquakes on the source. The weights are based upon assessment of all of the data supporting each interpretation. Weights assigned to multi-segment faults ("cascades") are based upon our subjective estimate of the likelihood that that fault will rupture in that combination of segments relative to the other possible combinations, and also express qualitatively our estimates of the relative frequencies of occurrence of the different segment combinations. The final weight for each map is obtained as the product of the weights of the individual branches that comprise the corresponding limb of the tree. The maps were ranked according to their weights relative to the highest weighted, best estimate, map.

\section{Model 2}

Model 2 is shown in Figures 3 and 4, and is based chiefly upon "thin-skinned" tectonic interpretations by Shaw and Suppe (1994), Suppe and Medwedeff (1990), and Namson and Davis (Namson and Davis, 1988, 1990, 1992; Davis and Namson, 1994a,b; Davis et al., 1989; Namson and Lettis, 1993). Many of the important sources in this model are major blind thrust ramps on regional-scale detachments that are inferred by balanced cross-section modeling (see Phase 1 report). Therefore, the geometries, and particularly depths and slip rates of these thrusts are model-dependent and highly nonunique. This and the possible alternative interpretations of the relationships of surface faults to the detachments (Figure 4) mean that the epistemic uncertainties inherent in this model are large compared with Model 1. The slip rates for Model 2 given in Table 2 are preliminary only.

\section{GROUND MOTION ATTENUATION MODEL}

\section{Introduction}

Given the state of knowledge about ground motion, the approach to deriving ground motion information for this project was to use Western US ground motion descriptions developed by several experts. The assumptions underlying our are:

- The ground motion parameter, e.g. peak ground acceleration (PGA), is a lognormal stochastic variable $($ median $=a 50$, variability $=\sigma i n)$ 
- The median of the ground motion parameter is a function of earthquakc magnitude and distance and other source parameters included in ground motion models.

- The variability of the ground motion is quantified by the standard deviation of the natural logarithm of the ground motion parameter.

Given these assumptions, the data, data analyses and the methodologies used to develop the ground motion models were reviewed to assess their adequacy for estimating median ground motion and variability as a function of magnitude and distance. The results of this review was presented by Dr. N. Abrahamson at the August, 1995 Stanford workshop.

\section{Review of Ground Motion Models}

The attenuation relations considered in this study are:

Boore, Joyner, and Fumal (1993, 1994)

Sadigh (1994)

Campbell (1990)

Campbell and Bozorgnia (1994)

Abrahamson and Silva (1997)

CB Crouse (personal communication, 1995)

"C-Cubed" simulation studies (Southern California Earthquake Center, 1995)

The distance definitions used by different models are:

Sadigh: $\quad \mathrm{d} 1$ or "rupture distance" = closest distance to the rupture plane

Campbell: $\quad \mathrm{d} 2$ or "seismogenic distance" = closest distance to the seismogenic part of the rupture

Boore et al.: $\quad d 3=$ closest distance to the vertical projection of the rupture

Because the attenuation models use different distance definitions, each attenuation model is converted to use $\mathrm{dl}$ as the distance measure. 
The reference site condition was selected as stiff soil. Four source geometries representing typical geometries in the earthquake source models were used:

$$
\begin{aligned}
& \text { Dip }=30, \text { top edge of fault }=7 \mathrm{~km} \text { (hanging wall and footwall) } \\
& \text { Dip }=90, \text { top edge of fault }=0 \mathrm{~km} \\
& \text { Dip }=70, \text { top edge of fault }=0 \mathrm{~km} \text { (hanging wall and footwall) } \\
& \text { Dip }=30, \text { top edge of fault }=15 \mathrm{~km} \text { (hanging wall and footwall) }
\end{aligned}
$$

\section{Ground Motion Input}

In this study the ground motion measures considered are PGA and pseudospectral velocities (PSV) at periods of $0.1,0.2,0.5,1.0,2.0$, and $4.0 \mathrm{sec}$. Using the above ground motion models, parameters of the ground motion frequency distributions were derived for 88 magnitude-distance pairs:

$$
\begin{aligned}
& \text { Magnitude }=4.5,5.0,5.5,6.0,6.5,7.0,7.5,8.0 \\
& \text { Distance }=1,3,5,7,10,15,20,30,50,100,300 \mathrm{~km}
\end{aligned}
$$

For each of the 88 magnitude-distance pairs, the parameters of the conditional ground motion frequency distribution, given $(\mathrm{m}, \mathrm{r})$, are:

- Median ground motion (a50): the 50\% frequency of exceedence ground motion level, represented by a lognormal distribution (median and logarithmic standard deviation).

- Variability of the ground motion (믹): represented by a lognormal distribution (median and logarithmic standard deviation).

- Limits on variability of the ground motion levels.

\section{Composite Ground Motion Uncertainty Distribution}

The assessment of ground motion levels from different attenuation models were combined at each of the 88 magnitude-distance pairs and translated into uncertainty distributions for a 50 and $\sigma \mathrm{ln}$. The composite uncertainty distribution is expressed in terms of: 
- Uncertainty distribution for a50: given in terms of fractiles

- Empirical conditional uncertainty distribution for $\underline{\sigma} \underline{\underline{n}}$, given each of the fractiles of a 50

\section{Extrapolation in Magnitude and Distance}

Since ground motion frequency distributions must be available for all magnitudedistance pairs, it is necessary to extrapolate the composite uncertainty distribution to all values of magnitude and distance. This was done analytically by fitting models, in terms of magnitude and distance, to the fractiles of the uncertainty distribution for a50 and the parameters of the conditional uncertainty distributions for oln. The models used for the fractiles of a50 are of the form:

$$
\mathrm{a} 50, \mathrm{a}=\mathrm{c} 1, \mathrm{a}+\mathrm{c} 2, \mathrm{a}^{*} \mathrm{~m}+\mathrm{c} 3, \mathrm{a} * \mathrm{r}+\mathrm{c} 4, \mathrm{a} * \ln \mathrm{r}+\mathrm{c} 5, \mathrm{a}^{*} \mathrm{~m} * \ln +\mathrm{c} 6 *(8.5-\mathrm{m}) 2 \mathrm{r}>\mathrm{ro}
$$

The models used for representing the parameters of the variable $\sigma \ln$, defined as a lognormal distribution, are piece wise constant and dependent only on magnitude.

\section{Use of the Composite Ground Motion Uncertainty Distribution in Seismic Hazard}

\section{Calculations}

Given the composite joint uncertainty distribution for a50 and oln, the following outlines the procedure for deriving a ground motion frequency distribution. For a given simulation of the seismic hazard calculation:

- Sample a random number between 0 and 1 to select a fractile of a50: a50,a

- Given the selection of the fractile, calculate a50,a

- Given a50,a, select the parameters of the conditional distribution of oln.

- Randomly sample the value of oln, given the parameters of $\sigma \ln$. 
The resulting a50,a and valuc of oln are then use to calculate the probability of exceeding a given ground motion level, given magnitude and distance.

\section{MODEL 1 HAZARD CALCULATIONS}

The hazard curves for peak ground acceleration (PGA) shown in Figures 5-7 were calculated using the method described by Bernreuter et al. (1989) and the Model 1 source characterization. The calculations were performed for three sites, platforms Houchin (Federal OCS P-0166), Dos Quadras A (Federal OCS P-0241) and Pescado A-1, shown on Figures 1 and 3. Five hundred Monte Carlo simulations were performed for each site, one of the Model 1 source maps being selected for each simulation. Rather than sampling the entire space of source maps (in the present case $\sim 10^{6}$ maps), only the 100 highest weighted maps were used to represent the overall map distribution. This procedure is justified by the fact that the relative weights of the ranked maps drop rapidly once low weighted alternatives (branches) begin to be included. Therefore, the hazard estimates stabilize at the values that result from a relatively small subset containing the highest weighted maps.

Each simulation sampled one value of the earthquake rate distribution at each magnitude in the range $m_{0} \leq m \leq m_{u}$ and one value of the distribution of $m_{u}$ to construct the magnitude frequency distribution for each source in the map. The earthquake-site distance distributions were constructed as described in Savy (1993). Each simulation sampled one value of the ground motion distribution for each magnitude and distance for each source.

\section{Discussion of Results}

Hazard estimates for the Houchin, Dos Cuadras and Pescado sites have been reported by Staal, Gardner and Dunne (1990a), Staal, Gardner and Dunne (1990b) and Vyas et al.(1983), respectively. The hazard estimates in these reports are stated in terms of the 200 and $\sim 1000$ year ground motions, consistent with American Petroleum Institute (API) recommendations for strength- and ductility-level events (see API, 1993, 1994). The 200 and $\sim 1000$ year return period PGA values estimated from the previous analyses are plotted on Figures 5-7 for comparison with the mean hazard curves. Hazard results for the Houchin and Dos Cuadras sites were reported by Staal, Gardner and Dunne $(1990 \mathrm{a}, \mathrm{b})$ in terms of pseudo-spectral velocities (PSV), and include PSV response spectra 
for the 200 and 1000 year events. The comparison (i.e. previous) PGA values for these two sites plotted in Figures 5 and 6 were estimated from the $0.15 \mathrm{sec}$. period PSV values for 200 and 1000 years by extrapolating to $0.033 \mathrm{sec}$. along the response spectral shape given in the Houchin and Dos Cuadras reports and differentiating PSV to obtain PGA. Therefore, these comparison values are only approximate. Vyas et al.(1983) give approximate upper bound PGA estimates for the Pescado site of $0.2 \mathrm{~g}$ and $0.3 \mathrm{~g}$ for 200 and $\sim 1000$ year return periods, respectively.

Figures 5-7 show that the mean PGA hazard curves obtained using Model 1 alone are comparable with the results of the previous analyses, which fall within the uncertainty bounds of the hazard curves. This is largely because the source models used for those analyses include many of the same local (Western Transverse Ranges) faults as Model l, although the geometries and rate parameterizations of these faults differ from Model 1 to varying degrees, and significant sources such as the Oak Ridge blind thrust are absent from the previous models. Epistemic uncertainties in the hazard are discussed in none of the previous reports. We anticipate that including source Model 2 in the PSHA will widen the uncertainty bounds shown in Figures 5-7. This is first because Models 1 and 2 are based upon fundamentally different tectonic hypotheses, so that including Model 2 in itself introduces significant epistemic uncertainty into the source characterization. Secondly, many of the Model 2 sources that have the potential for making the greatest contribution to the hazard in the Channel are blind thrust faults, which, as discussed earlier, have associated epistemic uncertainties that are significantly greater than those associated with most of the Model 1 sources. However, the large epistemic uncertainties associated with Model 2 also mean that this model receives an overall lower weight relative to Model 1, which should significantly mitigate the effect that the Model 2 uncertainties have on the hazard uncertainty.

\section{FUTURE WORK}

The following steps are needed to complete the PSHA: (1) Complete characterization and weighting of the Model 2 sources and incorporate Model 2 into the hazard calculations; (2) include residual background seismicity and more distant regional sources that potentially contribute to the hazard at long periods in the PSHA. The regional source characterizations developed by the Southern California Earthquake Center (SCEC) (Working Group on California Earthquake Probabilities, 1995) and by the California Division of Mines and Geology (Petersen et al., 1996; USGS/CDMG open file 
report, in preparation) will be adopted for this purpose. Models 1 and 2 are designed to fit within these regional source models. (SCEC and CDMG continue to make significant modifications to their models, in part motivated by the work described in this report.); (3) verify that the mean total seismic moment rate produced by the source models satisfy the moment rate budget imposed by global plate motion model and geodetic constraints; (4) perform hazard calculations using the full characterization of the ground motion model; (5) calculate a suite of ground motion parameters. including spectral acceleration and velocity at given periods; (6) produce contoured hazard maps; (6) perform sensitivity and de aggregation analyses to identify the sources that make the major contributions to the hazard at given levels of exceedence and at given periods. 


\section{REFERENCES}

Abrahamson, N.A., and W.J. Silva, Empirical response spectral attenuation relations for shallow crustal earthquakes, in press, Seismol. Res. Let., 1997.

American Petroleum Institute, Proposed revisions to RP2A-WSD Recommended Practice for Planning, Designing, and Constructing Fixed Offshore Platforms-Assessment of Existing Platforms - Draft Section 17, Dallas, TX, 1994.

American Petroleum Institute, Recommended Practice for Planning, Designing, and Constructing Fixed Offshore Platforms, API Recommended Practice 2A (RP2ALFRD), 12th Edition, Dallas, TX, 1993.

Bernreuter, D.L., J.B. Savy, R.W. Mensing, and J.C. Chen, Seismic hazard characterization of 69 nuclear plant sites east of the Rocky Mountains, Report NUREG/CR-1582, vols. 1-5, prepared by Lawrence Livermore National Laboratory for the U.S. Nuclear Regulatory Commission, 1989.

Boore, D.M., W.B. Joyner, and T. Fumal, Estimation of response spectra and peak acceleration from western North American earthquakes: An interim report, US Geological Survey, Open File Report 93-509, 1993.

Boore, D.M., W.B. Joyner, and T. Fumal, Estimation of response spectra and peak acceleration from western North American earthquake, communication to SCEC, 1994.

Campbell, K.W., and V. Bozorgnia, Near-source attenuation of peak horizontal acceleration form worldwide accelerograms recorded from 1957 to 1993 , Proc. 5th National Conference on Earthquake Engineering, 1994.

Clark, M.M. et al., Preliminary slip-rate table for late Quaternary faults in California, U.S.G.S. Open File Rep. 84-106, 1984.

Colson, K.B., T.K. Rockwell, M. K.M. Thorup, and G.L. Kennedy, Neotectonics of the left-lateral Santa Rosa Island fault, western Transverse Ranges, Southern California, Geol. Soc. Am. Abstracts with Programs, 27, 11, 1995.

Darrow, A.C., and Sylvester, A.G, 1984, Final technical report activity of the central reach of the Santa Ynez Fault: Continuation of investigations, USGS contract no. 1408-0001-21367.

Davis, T. L., and Namson, J. S., A balanced cross-section of the 1994 Northridge earthquake, Southern California, Nature, 372, 10, 167-169, $1994 \mathrm{~b}$.

Davis, T.L., J. Namson and R.F. Yerkes, A cross section of the Los Angeles area: Seismically active fold and thrust belt, the 1987 Whittier Narrows earthquake, and earthquake hazard, J. Geophys. Res., 94, 9644-9664, 1989.

Davis., T.L., and J. Namson, Structural analysis and seismic potential evaluation of the Santa Monica Mountains anticlinorium and Elysian Park thrust system of the Los Angeles Basin and Santa Monica Bay, U.S. Geol Survey National Earthquake Hazards Reduction Program Report, Award No. 1434-93-G-2292, 13 p., 1994a. 
Fischer, P.J., and G.W. Simila, North Channel Slope fault, Santa Barbara Basin, California: A reevaluation (abs.), Amer. Assoc. Petrol. Geol. Bull., 67, 461, 1983.

Hornafius, J.S., M.J. Kamerling, and B.P. Lyundyk, Seismic mapping of the North Channel fault near Santa Barbara, CA, 1995 Progress Report to the Southern California Earthquake Center, 3 p., 1995.

Huftile, G.J., and R.S. Yeats, Convergence rates across a displacement transfer zone in the western Transverse Ranges, Ventura Basin, California, J. Geophys. Res., 100, 2043-2067, 1995.

Huftile, G.J., and R.S. Yeats, Deformation rates across the Placerita (Northridge $\mathrm{M}_{\mathrm{W}}=$ 6.7 Aftershock Zone) and Hopper Canyon segments of the Western Transverse Ranges deformation belt, Bull. Seis. Soc. Am., 86, S3-S18, 1996.

Jackson, P. A., and Yeats, R. S., 1982, Structural evolution of Carpinteria Basin, Western Transverse Ranges, California, American Association of Petroleum Geologists Bulletin, vol. 66, no. 7, p. 805-829.

Levi, S., and R.S. Yeats, 1993, Paleomagnetic constraints on the initiation of uplift on the Santa Susana fault, Western Transverse Ranges, California, Tectonics, 12, 688-702.

Luyendyk, B. P., Hajic, E. J., Crippen, R. E., and Simonett, D. S., 1982, Side scan sonar and high resolution reflection maps of the Santa Barbara Channel seafloor, UCSB, California Sea Grant College Program Report no. T-CSGCP-006.

McGill, J. T., 1989, Geologic maps of the Pacific Palisades area, Los Angeles, California, U. S. Geological Survey Map I-1828, scale 1:4,800.

Namson, J., and Davis, T, Structural transect of the Western Transverse Ranges, California: Implications for lithospheric kinematics and seismic risk evaluation, Geology, 16, 675-679, 1988.

Namson, J., and Davis, T. L., Late Cenozoic fold and thrust belt of the southern Coast Ranges and Santa Maria Basin, California, Amer..Assoc. Petrol. Geol. Bull., 74, 467492, 1990.

Namson, J., and Davis, T., Late Cenozoic thrust ramps of southern California, Final Report for 1991 Contract, Southern California Earthquake Center, 1992

Namson, J.S., and W.R. Lettis, Balanced cross section through the Western Transverse Ranges in the Vicinity of Bradbury dam, Report prepared by Wiliam Lettis and Assoc. and Davis and Namson Consulting Geologists for the U.S. Bureau of Reclamation, Denver, CO, 9 p., 1993.

Petersen, M.D., and S.G. Wesnousky, 1994, Fault slip rates and earthquake histories for active faults in southern California, Bull. Seis. Soc. Am., 84, 1608-1649.

Petersen, M.D., C.H. Cramer, W.A. Bryant, M.S. Reichle, and T.R. Toppozada, Preliminary seismic hazard assessment for Los Angeles, Ventura, and Orange Counties, California, affected by the 17 January 1994 Northridge earthquake, Bull. Seis. Soc. Am., 86, S247-S261, 1996. 
Rockwell, T., 1988, Neotectonics of the San Cayetano fault, Transverse Ranges, California, Geological Society of America Bulletin, vol. 100, p. 500-513.

Rockwell, T., 1995b, Paleoseismic studies in the Los Angeles area, SCEC 1994 Annual Report, v.2: 1994 Progress Report from SCEC Scientists, C26-C27.

Rockwell, T.K., E.R. Keller, M.N. Clark, and D.L. Johnson, Chronology and rates of faulting of Ventura River terraces, California, Geol. Soc. Am. Bull., 95, 1466-1474, 1984.

Rockwell, T.K., J. Nolan, D.L. Johnson, and R.H. Patterson, Ages and deformation of marine terraces between Point Conception and Gaviota, Western Transverse Ranges, California, in Quaternary Coasts of the United States: Marine and Lacustrine Systems, Soc. Econ. Paleontologists and Mineralogists Special Publication No. 48, 333-341, 1992.

Sadigh, R.. Updated soil attenuation relations and standard errors, communication to SCEC, March, 1994.

Savy, J.B., UCRL ID 111115 , Lawrence Livermore National Laboratory, 1993.

Southern California Eathquake Center, $\mathrm{C}^{3}$ Study, Technical report submitted to California Dept. Transportation, Nov., 1995.

Senior Seismic Hazards Analysis Committee (SSHAC), Recommendations for probabilistic seismic hazard analysis: Guidance on uncertainty and use of experts, UCRL-ID-122160, Lawrence Livermore National Laboratory, 170 p, 1995.

Shaw, J. H., and Suppe, J., 1994, Active faulting and growth folding in the eastern Santa Barbara Channel, California, Geological Society of America Bulletin, vol. 106, p. 607-626.

Silva, W.J., and N.A. Abrahamson, Empirical attenuation relation for long period ground motions, Seis. Res. Let., 64, 20, 1993.

Sorlien, C. C., 1994, Faulting and uplift of the northern Channel Islands, California, in, Halvorson, W. L., and Maender, G. J., eds., The Fourth Channel Islands Symposium: Update on the Status of Resources, Santa Barbara Museum of Natural History, Santa Barbara, California, in press.

Staal, Gardner and Dunne, Inc., Seismic hazard analysis Platform A Federal OCS P-0241 Dos Cuadras Offshore Oil Field, Santa Barbara Channel, California, report prepared for Unocal Corp., 25 p., $1990 \mathrm{~b}$.

Staal, Gardner and Dunne, Inc., Seismic hazard analysis Platform Houchin Federal OCS P-0166 Carpenteria Offshore Oil Field, Santa Barbara Channel, California, report prepared for Phillips Petroleum Company, 26 p., 1990a.

Suppe, J., and D.A. Medwedeff, Geometry and kinematics of fault-propagation folding, Ecologae Geol. Helvetica, 83/3, 409-454, 1990.

Vyas, Y.K., D.A. Coats, and R. Henke, Earthquake design criteria for the Pescado A-1 platform site, report prepared by Exxon Production Research Co., 80 p., 1983. 
Wells, D.L., and K.J. Coppersmith, New empirical relationships among magnitude, rupture length, rupture width, rupture area, and surface displacement, Bull. Seis. Soc. Am., 84, 974-1002, 1994.

Working Group on California Earthquake Probabilities, Seismic hazards in Southern California: Probable earthquakes, 1994-2024, Bull. Seis. Soc. Am., 85, 379-439, 1995.

Yeats, R.S., Neogene tectonics of the central Ventura Basin, California, in A.E. Fritsche, H. Terbest., and W.W. Wornardt, eds., The Neogene Symposium, Pacific Sec., Soc. Econ. Paleontologists and Mineralogists, 19-32, 1976.

Yeats, R. S., 1988, Late Quaternary slip rates on the Oak Ridge Fault, Transverse Ranges, California: Implications for seismic risk, Journal of Geophysical Research, vol. 93 no. B10, p.12137-12150.

Yeats, R.S., Converging more slowly, Nature, 366, 299-301, 1993.

Yeats, R. S., and Huftile, G. J., 1995, The Oak Ridge fault system and the 1994 Northridge earthquake, Nature, 373, 418-420.

Yeats, R. S., and Olson, D. J., 1984, Alternate fault model for the Santa Barbara, California, earthquake of 13 August 1978, Bulletin of the Seismological Society of America vol. 74, p. 1545-1554.

Yeats, R. S.,; and Taylor, J. C., 1990, Saticoy oil field-U.S.A. Ventura Basin, California, in E. A. Beaumont and N. H. Foster, eds., Structural Traps III, Tectonic Fold and Fault Traps, Treatise of Petroleum Geology, Atlas of Oil and Gas Fields, American Association of Petroleum Geologists, Tulsa, Oklahoma, p. 199-215.

Yeats, R. S., Huftile, G. J., and Grigsby, F. B., 1988, Oak Ridge fault, Ventura fold belt, and the Sisar décollement, Ventura Basin, California, Geology, vol. 16, p. 1112-1116.

Yerkes, R.F., H.G. Greene, J.C. Tinsley, and K.R. Lajoie, Maps showing seismotectonic setting of the Santa Barbara Channel area, California, U.S. Geol. Surv. Misc. Field Studies Map MF-1169, 1981.

Yerkes, R.F., H.G.Greene, J.C. Tinsley, and K.R. Lajoie, Seismotectonic setting of Santa Barbara Channel area. Southern California, U.S. Geol. Surv. Open File Report 800299, 42 p., 1980.

Youngs, R.R., and K.J. Coppersmith, Implications of fault slip rates and earthquake recurrence models to probabilistic seismic hazard estimates, Bull. Seis. Soc. Am., 75, 939-964, 1985. 
Table 1 Explanation

\section{Notes}

a. Slip rate in $\mathrm{mm} / \mathrm{yr}$

b. Time interval over which slip rate averaged

c. Maximum $\mathrm{M}_{\mathrm{W}}$ from area- $\mathrm{M}_{\mathrm{W}}$ relationship of Wells and Coppersmith (1994).

\section{Data Sources}

1. Rockwell et al., 1992

2. Darrow and Sylvester, 1984

3. Clark et al., 1984

4. Petersen and Wesnousky, 1994

5. Rockwell et al., 1984

6. Yeats and Olson, 1984

7. Jackson and Yeats, 1982

8. Rockwell, 1988

9. Huftile and Yeats, 1995

10. Huftile and Yeats, 1996

11. Yeats and Huftile, 1995

12. Levi and Yeats, 1993

13. Sorlien, 1994

14. Rockwell, 1995

15. Colson et al., 1995

16. Pintér et al. (in review)

17. Luyendyk et al., 1982

18. J. Dolan, personal communication

19. McGill, 1989

20. Fischer and Simila, 1983

21. Hornafius et al., 1995

22. Yerkes et al., 1980, 1981

23. G. Huftile, personal communication

24. Yeats, 1976

25. Yeats and Taylor, 1990

26. Yeats, 1988 
TABLE 1

SANTA BARBARA CHANNEL MODEL 1 SLIP RATES

\begin{tabular}{|c|c|c|c|c|c|c|c|}
\hline FAULT & SEGMENT & $\begin{array}{l}\text { DIP } \\
\text { Deg }\end{array}$ & $\begin{array}{l}\text { SLIP } \\
\text { SENSE }\end{array}$ & $\begin{array}{l}V_{\min }{ }^{a} \\
\mathrm{~mm} / \mathrm{yr}\end{array}$ & $\begin{array}{l}V_{\max }{ }^{a} \\
\mathrm{~mm} / \mathrm{yr}\end{array}$ & $\begin{array}{l}V_{b e^{a}} \\
m m / y r\end{array}$ & $\begin{array}{c}\text { Interval }^{b} \\
\mathrm{Ma}\end{array}$ \\
\hline Santa Yncz & $\begin{array}{l}\text { South Branch } \\
\text { Lake Cachuma } \\
\text { Central } \\
\text { East }\end{array}$ & $\begin{array}{l}70 S \\
70 S \\
70 S \\
70 S\end{array}$ & $\begin{array}{l}\text { LL-R } \\
\text { LL(-R) } \\
\text { LL-R } \\
\text { LL(-R) }\end{array}$ & $\begin{array}{l}0.05^{1,2.4} \\
0.05^{3.4} \\
0.05^{3.4} \\
0.05^{-}\end{array}$ & $\begin{array}{l}0.4^{3.2 .4} \\
1 \\
6.7^{3.4} \\
1\end{array}$ & $\begin{array}{l}0.1 \\
1 \\
1.0 \\
1\end{array}$ & $\begin{array}{l}0.08-.105^{1} \\
0.01-0.7^{3.4}\end{array}$ \\
\hline Arroyo Parida-Santa Ana & & $70 \mathrm{~S}$ & R(-LL?) & $0.3^{3.4}$ & $0.4^{5}$ & $0.4^{5}$ & $0.03-0.04^{5 \cdot 6.7}$ \\
\hline San Cayetano & $\begin{array}{l}\text { West } \\
\text { East }\end{array}$ & $\begin{array}{l}50 \mathrm{~N} \\
50 \mathrm{~N}\end{array}$ & $\begin{array}{l}\mathrm{R} \\
\mathrm{R}\end{array}$ & $\begin{array}{l}0.9^{8} \\
4.4^{10}\end{array}$ & $\begin{array}{l}5.8^{9} \\
10.4^{10.8}\end{array}$ & $\begin{array}{l}4.0^{8.9} \\
7.4^{10}\end{array}$ & $\begin{array}{l}0.008-0.02^{8} \\
0.5^{10}\end{array}$ \\
\hline Northridge & & $45 S$ & $\mathrm{R}$ & $1.0^{10}$ & $2.5^{10}$ & $1.7^{10.11}$ & $2.3^{10}$ \\
\hline Santa Susana & & $55 / 30 \mathrm{~N}$ & $\mathrm{R}$ & $2.1^{10}$ & $9.8^{10}$ & 6.0 & $0.6-2.3^{10.12}$ \\
\hline Santa Rosa Is. & & $85 \mathrm{~N}$ & LL(-R) & $0.1^{13}$ & $1.5^{14}$ & $0.75^{15.16}$ & \\
\hline Santa Cruz is. & $\begin{array}{l}\text { East } \\
\text { West }\end{array}$ & $\begin{array}{l}85 \mathrm{~N} \\
85 \mathrm{~N}\end{array}$ & $\begin{array}{l}\mathrm{LL}(-\mathrm{R}) \\
\mathrm{LL}(-\mathrm{R})\end{array}$ & $\begin{array}{l}0.1 \\
0.1\end{array}$ & $\begin{array}{l}1.25^{10} \\
1\end{array}$ & $\begin{array}{l}0.75^{16} \\
0.5^{17}\end{array}$ & \\
\hline Malibu Coast & & $85 \mathrm{~N}$ & LL(-R) & $<0.1^{3.4}$ & 1 & 0.3 & \\
\hline Santa Monica & & $85 \mathrm{~N}$ & LL-R & $0.3^{18}$ & 1 & $0.6^{19}$ & \\
\hline Dume & & $85 \mathrm{~N}$ & $\mathrm{R}(-\mathrm{LL} ?)$ & 0.5 & 3.5 & 2 & \\
\hline North Channel Slope & & $65 / 35 \mathrm{~N}$ & $\mathrm{R}$ & $0.1^{20.1}$ & $1.1^{21.22}$ & 0.5 & $0.08-1.821$ \\
\hline Red Mountain & $\begin{array}{l}\text { Central } \\
\text { East } \\
\text { West } 1 \\
\text { West } 2\end{array}$ & $\begin{array}{l}65 / 35 \mathrm{~N} \\
65 / 35 \mathrm{~N} \\
65 / 35 \mathrm{~N} \\
65 / 35 \mathrm{~N}\end{array}$ & $\begin{array}{l}\mathrm{R} \\
\mathrm{R} \\
\mathrm{R} \\
\mathrm{R}\end{array}$ & $\begin{array}{l}0.4^{7.9} \\
0.4^{7.9} \\
0.1 \\
0.1\end{array}$ & $\begin{array}{l}7.0^{9} \\
7.0^{9} \\
1.1 \\
1.1\end{array}$ & $\begin{array}{l}1.0^{7} \\
3.5 \\
0.5 \\
0.5\end{array}$ & $\begin{array}{l}0.045^{7} ; 0.5^{9} \\
0.045^{7} ; 0.5^{9}\end{array}$ \\
\hline Ojai Blind T & $\begin{array}{l}\text { West } \\
\text { East }\end{array}$ & $\begin{array}{l}30 \mathrm{~N} \\
30 \mathrm{~N}\end{array}$ & $\begin{array}{l}\mathrm{R} \\
\mathrm{R}\end{array}$ & $\begin{array}{l}6.0^{9.23} \\
2.6^{9.23}\end{array}$ & $6.2^{9,23}$ & $\begin{array}{l}6.1 \\
2.6\end{array}$ & $\begin{array}{l}0.5^{9} \\
0.5^{9}\end{array}$ \\
\hline Blind Oak Ridge & $\begin{array}{l}\text { Central } \\
\text { East } \\
\text { West }\end{array}$ & $\begin{array}{l}30 S \\
30 S \\
30 S\end{array}$ & $\begin{array}{l}\mathrm{R} \\
\mathrm{R} \\
\mathrm{R}\end{array}$ & $\begin{array}{l}4.0^{9} \\
4.0^{9} \\
4.0\end{array}$ & $\begin{array}{l}7.5^{9} \\
7.5^{9} \\
7.5\end{array}$ & $\begin{array}{l}5.0^{9} \\
5.0^{9} \\
5.0\end{array}$ & $\begin{array}{l}0.5^{9} \\
0.5^{9} \\
0.5\end{array}$ \\
\hline Oak Ridge & $\begin{array}{l}\text { West } \\
\text { East }\end{array}$ & $\begin{array}{l}85 / 50 \mathrm{~S} \\
70 / 50 \mathrm{~S}\end{array}$ & $\begin{array}{l}\text { R-L,L } \\
\text { R }\end{array}$ & $\begin{array}{l}4.8^{2+1.25 .9} \\
3.4^{10}\end{array}$ & $\begin{array}{l}5.6^{24,25} \\
5.0^{9,26}\end{array}$ & $\begin{array}{l}5.1^{24.25} \\
4.5^{2}\end{array}$ & $\begin{array}{l}0.975 \pm .075^{\circ} \\
0.59 .10\end{array}$ \\
\hline
\end{tabular}


TABLE 2

SANTA BARBARA CHANNEL MODEL 2 PRELIMINARY SLIP RATES

\begin{tabular}{|c|c|c|c|c|c|c|c|}
\hline FAULT & SEGMENT & $\begin{array}{l}\text { DIP } \\
\text { Deg }\end{array}$ & $\begin{array}{l}\text { SLIP } \\
\text { SENSE }\end{array}$ & $v_{\operatorname{mm} / \mathbf{y r}}^{V_{\min }}$ & $\begin{array}{l}V_{\max }{ }^{a} \\
\mathrm{~nm} / \mathrm{yr}\end{array}$ & $\begin{array}{c}v_{b e^{a}} \\
m m / y r\end{array}$ & $\begin{array}{c}\text { Interval }^{b} \\
\mathbf{M a}\end{array}$ \\
\hline Santa Lucia T. & & $25 \mathrm{NE}$ & $\mathrm{R}$ & 1.1 & 2.2 & 1.6 & $6-3$ \\
\hline \multirow[t]{2}{*}{ Pt. San Luis T. } & Tepesquet & $23 \mathrm{NE}$ & $R$ & 1.1 & 2.1 & 1.6 & $6-3$ \\
\hline & Figuora & $27 \mathrm{NE}$ & $\mathrm{R}$ & 0.6 & 2.3 & 1.7 & $6-3$ \\
\hline \multirow[t]{2}{*}{ Black Mtn. T. } & NW & $15 \mathrm{NE}$ & $\mathrm{R}$ & 1.3 & 3.1 & 2.1 & $6-3$ \\
\hline & SE & $23 \mathrm{NE}$ & $\mathrm{R}$ & 1.1 & 3.1 & 2.3 & $6-3$ \\
\hline Little Pine F. & & $55 \mathrm{NE}$ & $\mathrm{R}$ & 0.7 & 1.4 & 1.0 & $6-3$ \\
\hline Big Pine $F$. & W & 70NNE & $\mathrm{R}$ & & & $(1.5)$ & \\
\hline \multirow[t]{5}{*}{ San Cayctano T. } & Pt Conception & $20 \mathrm{~N}$ & $\mathrm{R}$ & 1.6 & 5.9 & 4.4 & $6-3$ \\
\hline & Santa Barbara & $20 \mathrm{~N}$ & $\mathrm{R}$ & 2.0 & 7.0 & 4.5 & $6-3$ \\
\hline & Ojai & $30 \mathrm{~N}$ & $\mathrm{R}$ & 3.2 & 7.0 & 5.1 & $6-3$ \\
\hline & SCT 1 & $20 \mathrm{~N}$ & $\mathrm{R}$ & 1.3 & 5.9 & 3.6 & $6-3$ \\
\hline & Fillmore & $20 \mathrm{~N}$ & $\mathrm{R}$ & 5.0 & 10.0 & 7.5 & $6-3$ \\
\hline (San Cayetano F.) & SCT2 & 55NNE & $\mathrm{R}$ & 0.55 & 3.7 & 2.1 & $6-3$ \\
\hline \multicolumn{2}{|l|}{ Pico $\mathrm{T}$. } & $40 \mathrm{~S}$ & $\mathrm{R}$ & 1.4 & $1.7^{\circ}$ & 1.6 & $2.3-2$ \\
\hline \multicolumn{2}{|l|}{ Channel Is. $T$. } & $15 \mathrm{~N}$ & $\mathrm{R}$ & & & 1.3 & 3 \\
\hline \multirow[t]{3}{*}{ Elysian Park T. } & Sa. Monica Mtns. & $20 \mathrm{~N}$ & $\mathrm{R}$ & 3.0 & 5.4 & 4.2 & $4-2.2$ \\
\hline & Sepulveda & $20 \mathrm{~N}$ & $\mathrm{R}$ & 3.0 & 5.4 & 4.2 & $4-2.2$ \\
\hline & Los Angeles & 20NE & $\mathrm{R}$ & 2.5 & 4.6 & 3.5 & $4-2.2$ \\
\hline Santa Rosa Is. F. & & $85 \mathrm{~N}$ & LL(-R) & 0.1 & 1.5 & 0.75 & \\
\hline \multirow[t]{2}{*}{ Santa Cruz Is. F. } & East & $85 \mathrm{~N}$ & LL(-R) & 0.1 & 1.25 & 0.75 & \\
\hline & West & $85 \mathrm{~N}$ & LL(-R) & 0.1 & 1 & 0.5 & \\
\hline \multicolumn{2}{|l|}{ Malibu Coast F. } & $85 \mathrm{~N}$ & I.I.(-R?) & $<0.1$ & 1 & 0.3 & \\
\hline \multicolumn{2}{|l|}{ Dume F. } & $70 N$ & $\mathrm{R}(-\mathrm{LL} ?)$ & 0.5 & 3.5 & 2 & \\
\hline \multicolumn{2}{|l|}{ Santa Monica F. } & $65 \mathrm{~N}$ & LL-R & 0.3 & 1 & 0.6 & \\
\hline \multirow[t]{2}{*}{ Sata Ynez F. } & $\begin{array}{l}\text { South Branch } \\
\text { Lake Cachuma }\end{array}$ & $\begin{array}{l}70 \mathrm{~S} \\
70 \mathrm{~S}\end{array}$ & $\begin{array}{l}R \\
R\end{array}$ & 0.05 & 0.4 & 0.1 & $0.08-0.105$ \\
\hline & & ius & & & & & $6-3$ \\
\hline
\end{tabular}




$\begin{array}{lllllll}\quad \text { Central } & 70 \mathrm{~S} & \mathrm{R} & 0.6 & 1.2 & 1.0 & 6-3 \\ \text { Pitas Pt. F. } & & & & & & 6-3 \\ \text { N. Channel Slope F. } & 65 \mathrm{~N} & \mathrm{R} & 0.8 & 1.5 & 1.0 & 6-3\end{array}$

\section{AI'TERNATIVE:}

Santa Ynez F.

$$
\begin{aligned}
& \text { S. Branch } \\
& \text { L. Cachuma } \\
& \text { Central }
\end{aligned}
$$

$70 \mathrm{~S} \quad$ LL-R

0.05

$70 \mathrm{~S}$

$$
\text { LL-R }
$$

Red Mtn. F.

East

Central

$65 / 35 \mathrm{~N}$

$\begin{array}{ll}65 / 35 \mathrm{~N} & \mathrm{R} \\ 65 / 35 \mathrm{~N} & \mathrm{R} \\ 65 / 35 \mathrm{~N} & \mathrm{R}\end{array}$

West2

$65 / 35 \mathrm{~N} \quad \mathrm{R}$

N. Channel Slope

$65 / 35 \mathrm{~N} \quad \mathrm{R}$

$65 \mathrm{~N}$

0.4

0.4
0.4
0.1

0.1

0.1

0.1

\begin{tabular}{|c|c|c|}
\hline $\begin{array}{l}0.4 \\
1 \\
6.7\end{array}$ & $\begin{array}{l}0.1 \\
1 \\
\therefore \quad 1.0\end{array}$ & $0.08-0.105$ \\
\hline $\begin{array}{l}7.0 \\
7.0 \\
1.1 \\
1.1\end{array}$ & $\begin{array}{l}3.5 \\
1.0 \\
0.5 \\
0.5\end{array}$ & $\begin{array}{l}0.045 ; 0.5 \\
0.045 ; 0.5\end{array}$ \\
\hline 1.1 & 0.5 & $0.08-1.8$ \\
\hline
\end{tabular}

Pitas Pt.

Offshore Oak Ridge

$70 \mathrm{~S}$

OS R




\section{FIGURE CAPTIONS}

Figure 1: Source Model 1.

Map showing Model 1 fault sources. Surface traces of model faults having dips greater than and less than $65^{\circ}$ are shown in red and blue, respectively. Upper edges of blind faults are shown in green. Green and blue rectangles are surface projections of the fault planes of blind faults and shallow-dipping $\left(\leq 65^{\circ}\right)$ surface faults, respectively. Fault name abbreviations: SYF-SB, -LC, -C, -E, Santa Ynez fault, south branch, Lake Cachuma, central, and eastern segments; NCSF, North Channel Slope fault; RMF-E, -C, -W, Red Mountain fault, eastern, central, west l+west2 segments; APF, Arroyo Parida-Santa Ana fault; PPF, Pitas Point fault; SCF-E, -W, San Cayetano fault, east, west segments; OBT, Ojai blind thrust, west+east segments, SSF, Santa Susana fault; NRF, Northridge blind fault: ORF, Oak Ridge fault, west teast segments; BORT-E, -C, -W, Oak Ridge blind thrust, east, central, west segments; SMF, Santa Monica fault; MCF, Malibu Coast fault; DF, Dume fault; SCIF-E. -W, Santa Cruz Island fault, east, west segments; SRIF. Santa Rosa Island fault. Magenta triangles are offshore platform sites

Figure 2: Source Model 1 Cross Sections.

Cross-sections AA, CC, DD, FF (see Figure 1) through source Model 1. Major alternative subsurface geometries shown dashed.

Figure 3: Source Model 2

Map showing Model 2 fault sources. Color coding and symbols the same as Figure 1. Fault abbreviations: SLT, Santa Lucia thrust; BMT-NW, -SE, Black Mountain thrust, northwest, southeast segments; PSLT-TEP, -FIG, Point San Luis thrust, Tepesquet, Figuora segments; BPF-LL, -R, Big Pine fault, left-lateral, reverse segments; LPF, Little Pine fault; SCT-PC, -SB, -OJ, -SCT1, -SCT2, -FIL, San Cayetano thrust, Point Conception, Santa Barbara, Ojai,, SCT1, SCT2 (surface San Cayetano fault), Fillmore segments; SYF-SB,-LC, -C, Santa Ynez fault, south branch, Lake Cachuma, central segments; NCSF, North Channel Slope fault, RMF, Red Mountain fault, [east, central, west 1, west2 segments (see Figure 1)]; APF, Arroyo Parida-Santa Ana fault; PF, Pico fault; EPT-LA, -SEP, Elysian Park thrust, Los Angeles, Sepulveda segments; SMMT, Santa Monica Mountains thrust; CIT, Channel Islands thrust; SMF, Santa Monica fault; MCF, Malibu Coast fault; DF, Dume fault; SCIF-E, -W, Santa Cruz Island fault, east, west segments; SRIF, Santa Rosa Island fault.

Figure 4: Model 2 Cross Sections

Cross-sections BB, B'B', CC, FF (see Figure 3) through source Model 2. Section B'B' shows a major alternative interpretation to the geometry shown in $\mathrm{BB}$, in which the shallow San Cayetano detachment does not exist. 
Figure1. SOURCE MODEL 1

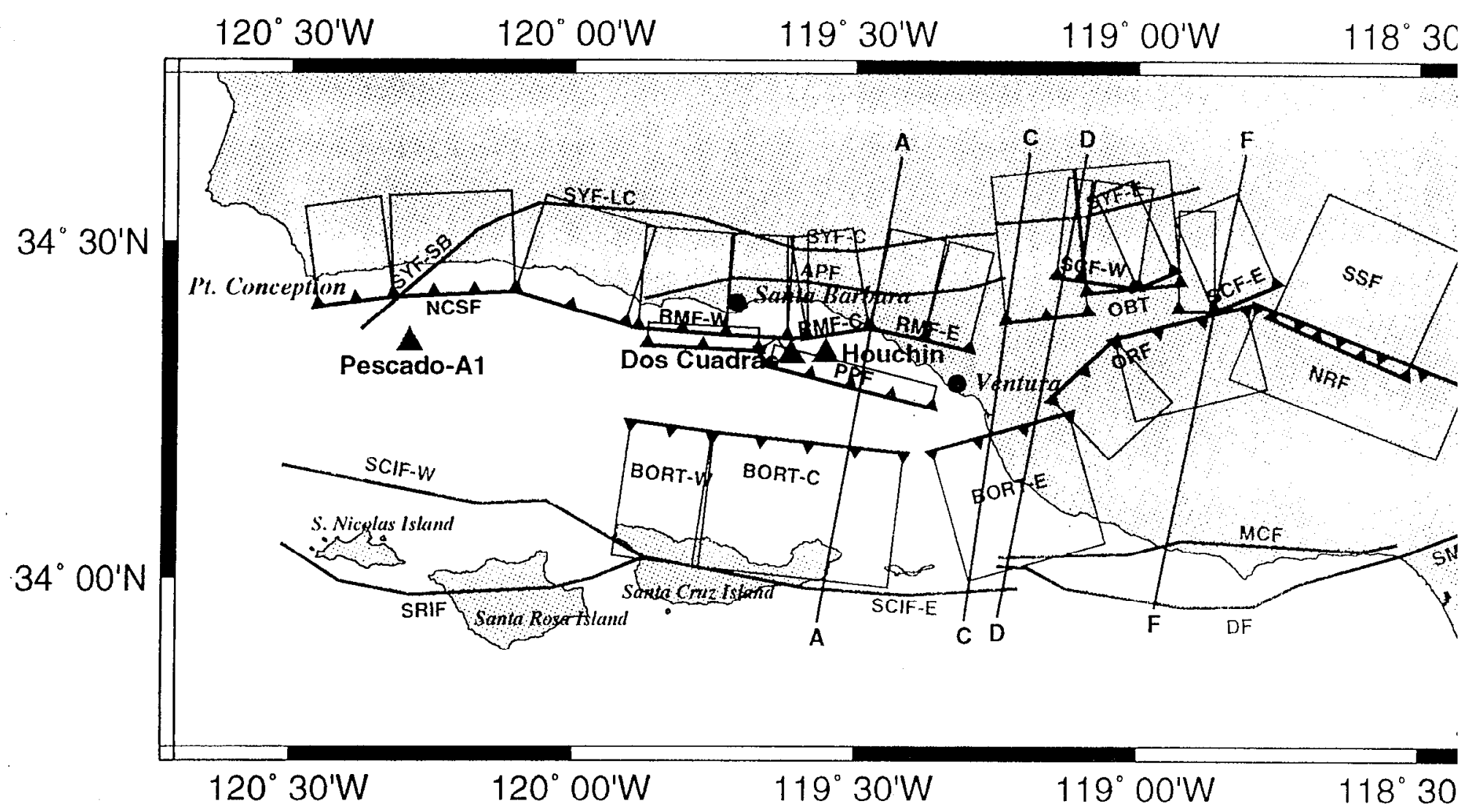



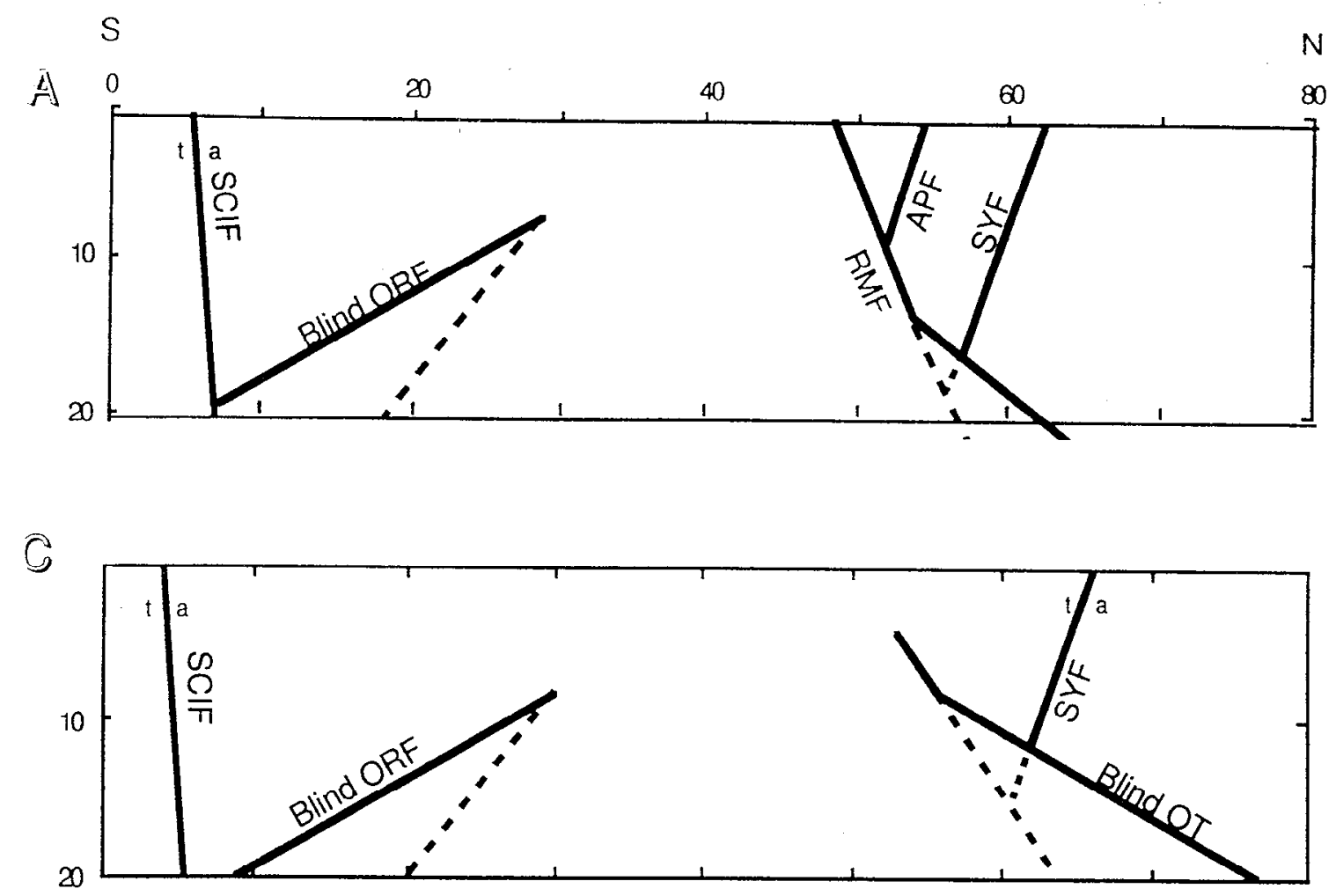

D

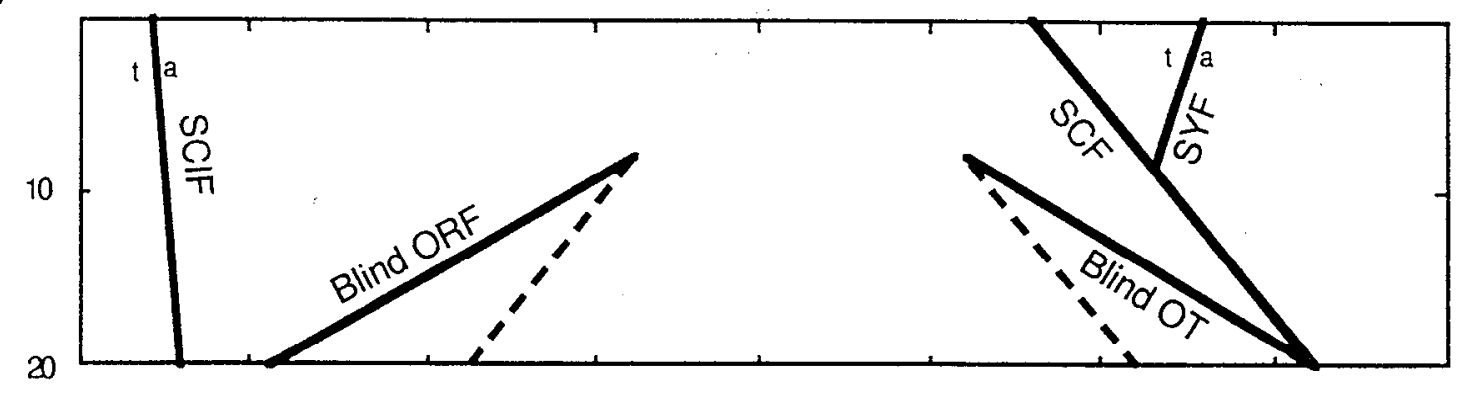

단

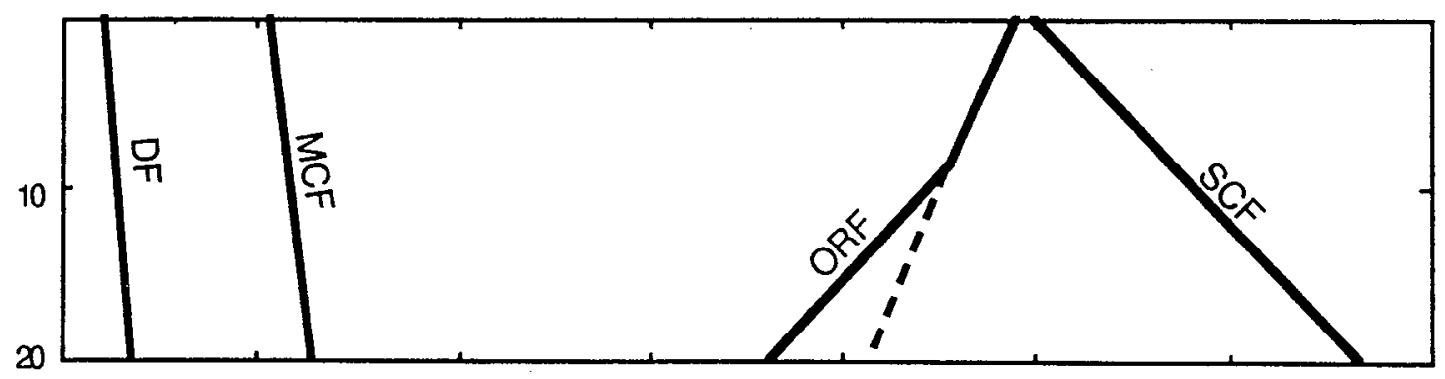

Figure 2: Model 1 Cross Sections 
Figure3. SOURCE MODEL 2

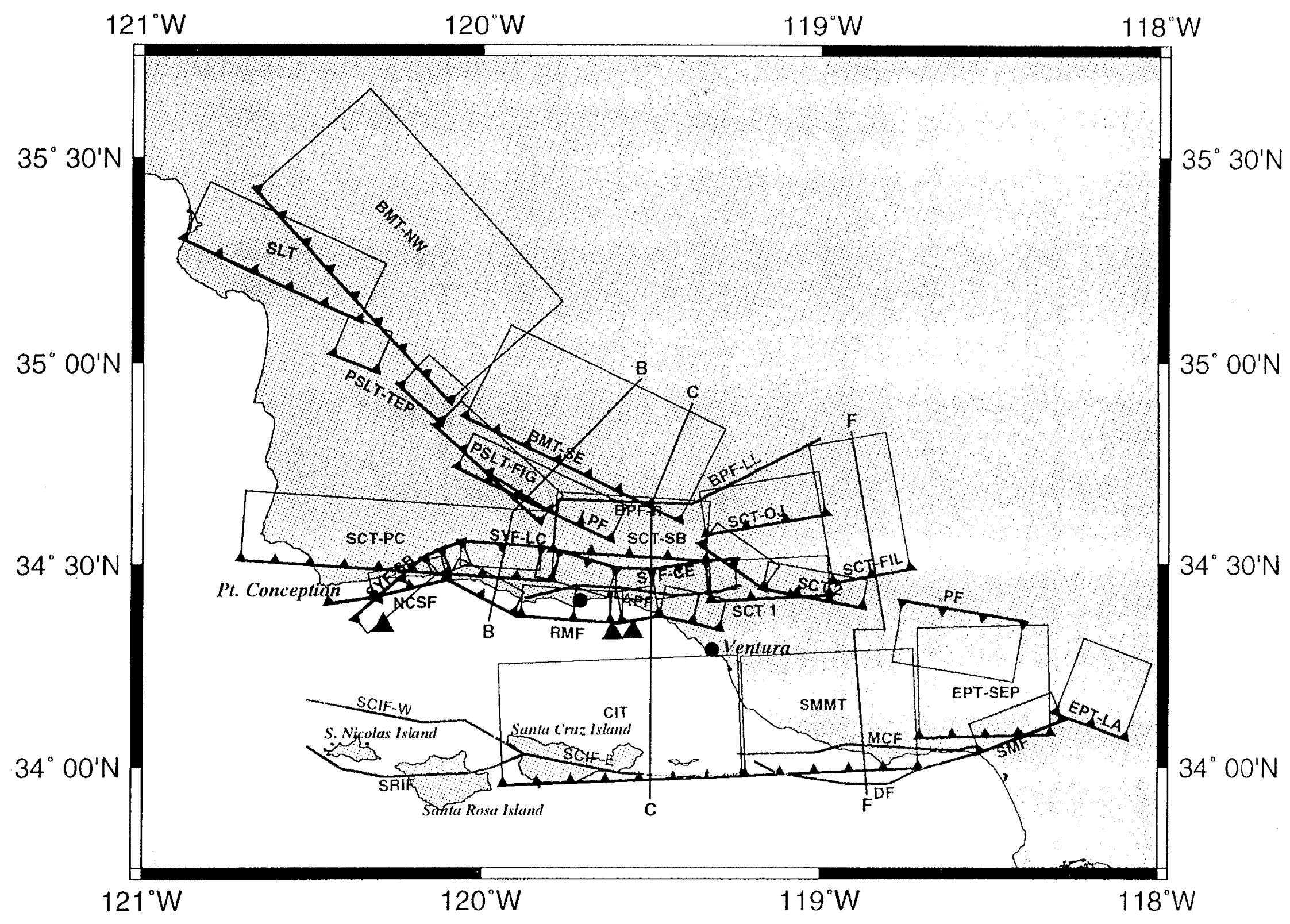




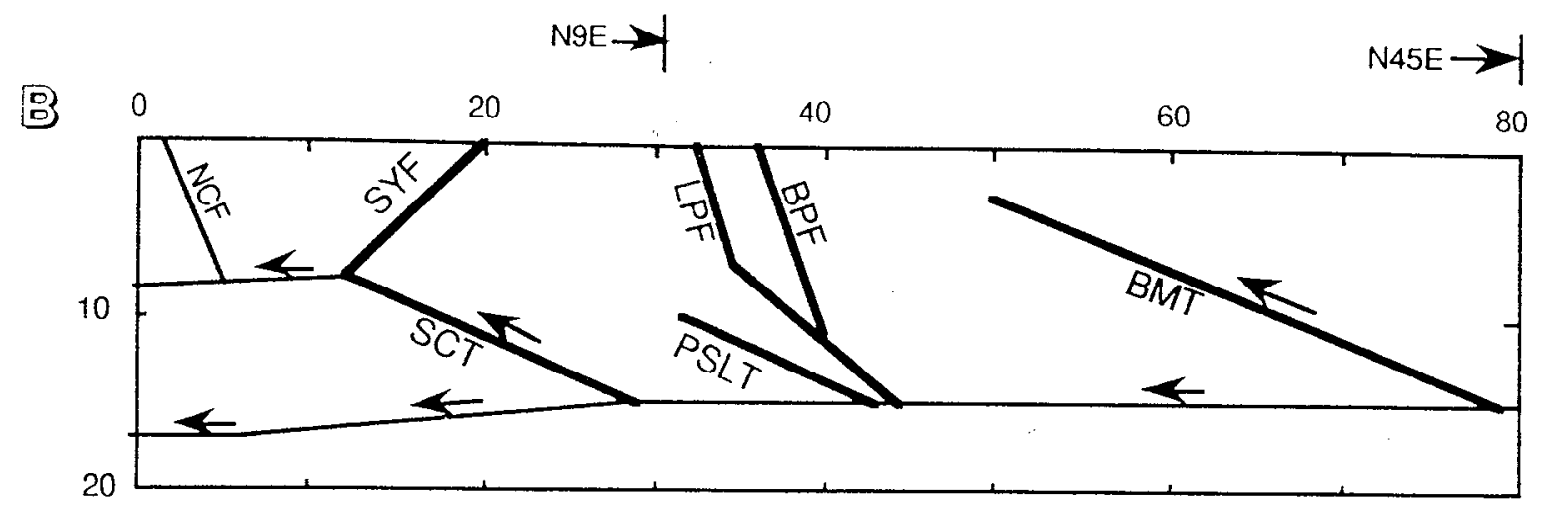

昌 $^{\circ}$
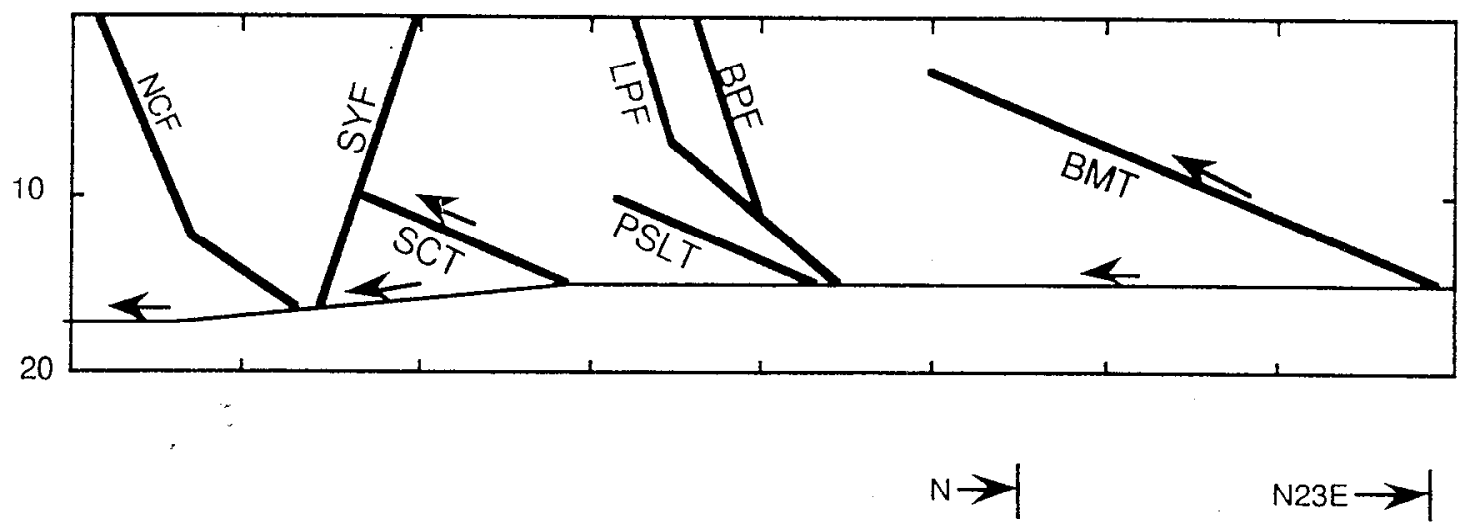

(C)

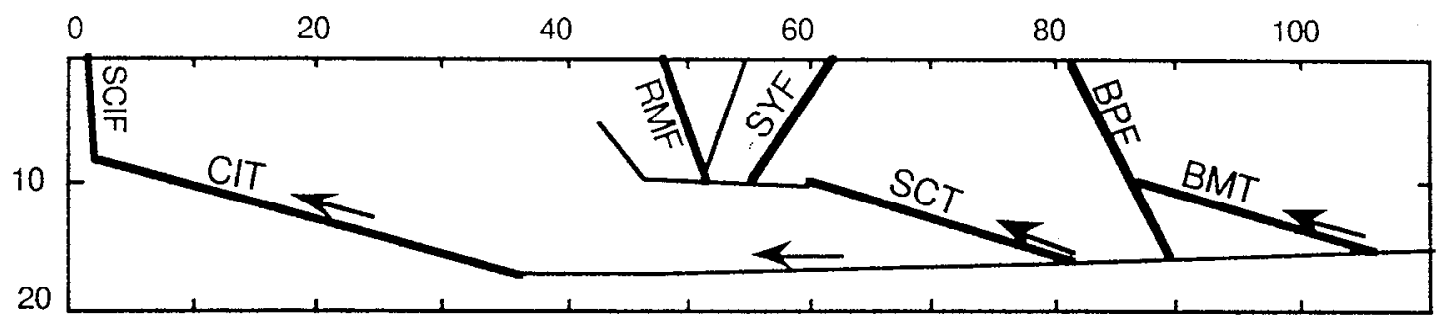

5

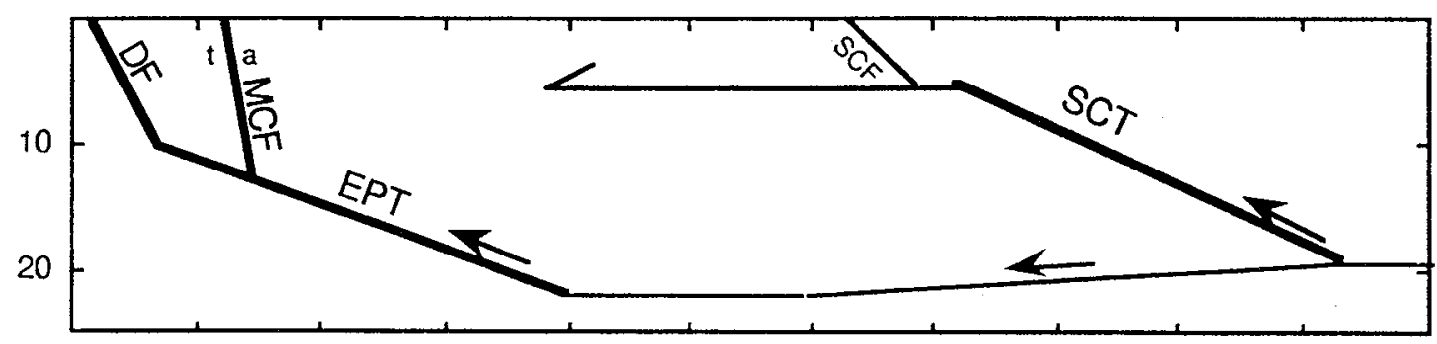

Figure 4: Model 2 Cross Sections 
Figure 5

\section{PLATFORM HOUCHIN HAZARD CURVE}
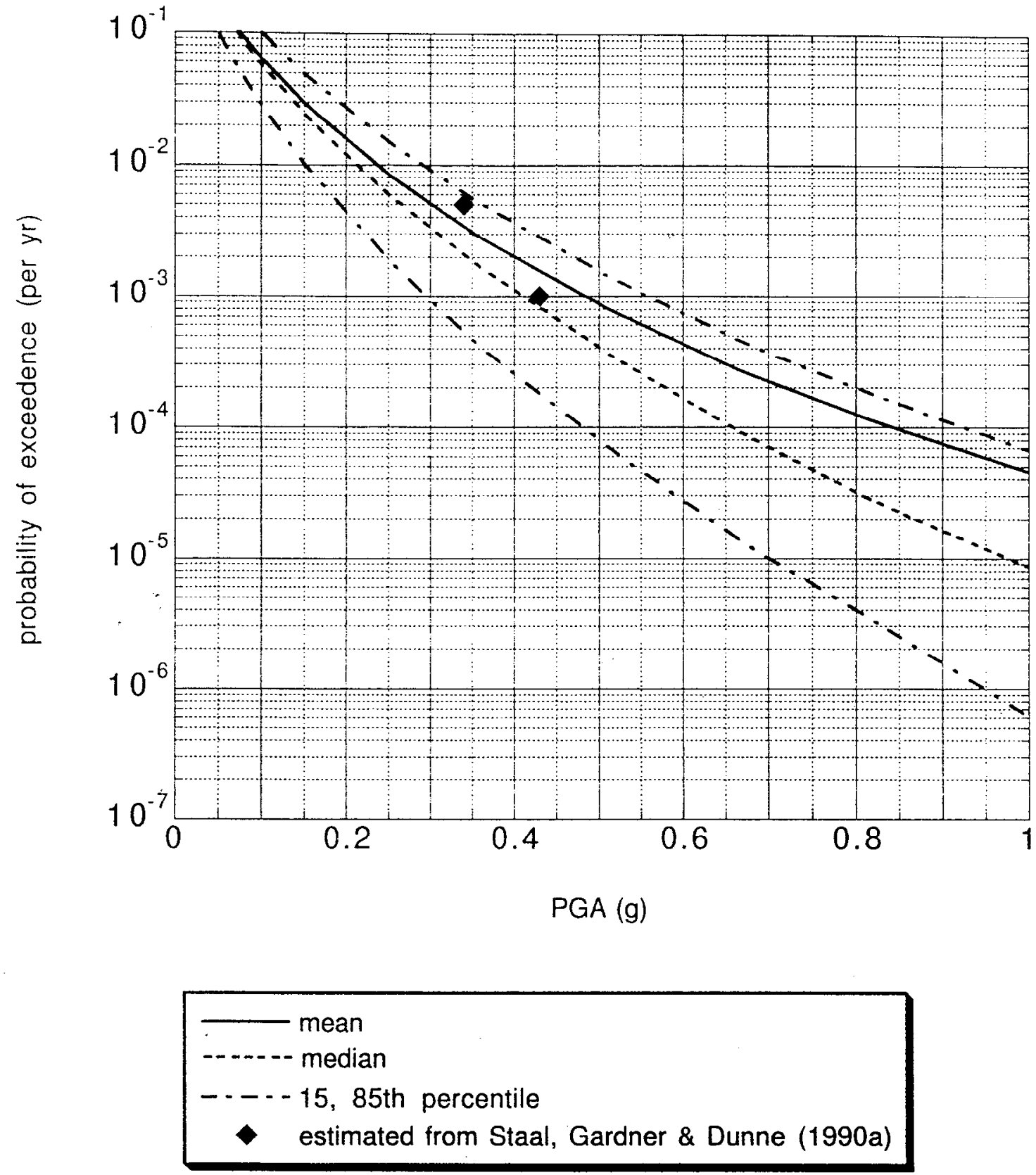
Figure 6

\section{PLATFORM DOS QUADRAS HAZARD CURVE}

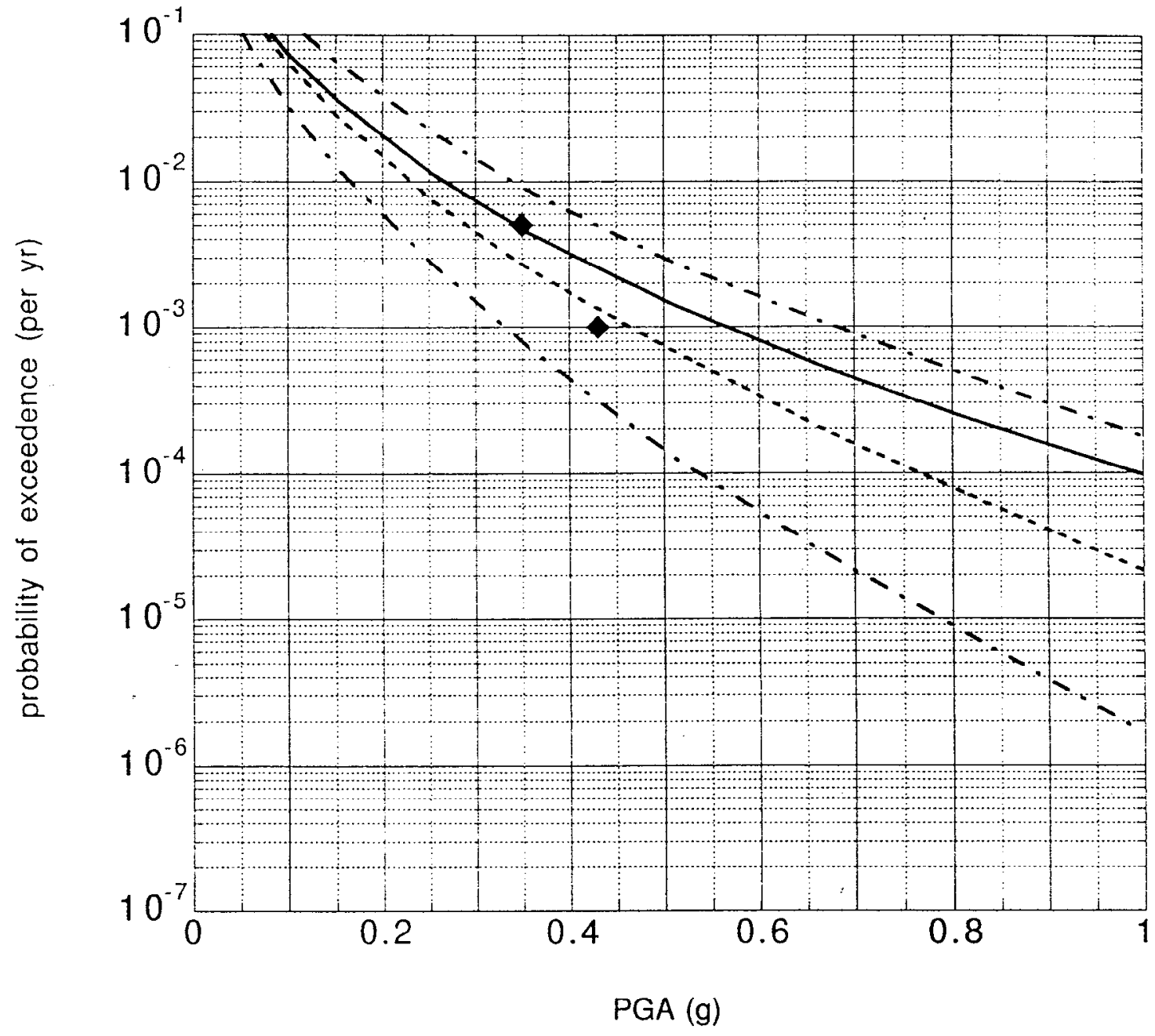

- 15, 85th percentile

- estimated from Staal, Gardner \& Dunne (1990b) 
Figure 7

\section{PLATFORM PESCADO-A1 HAZARD CURVE}
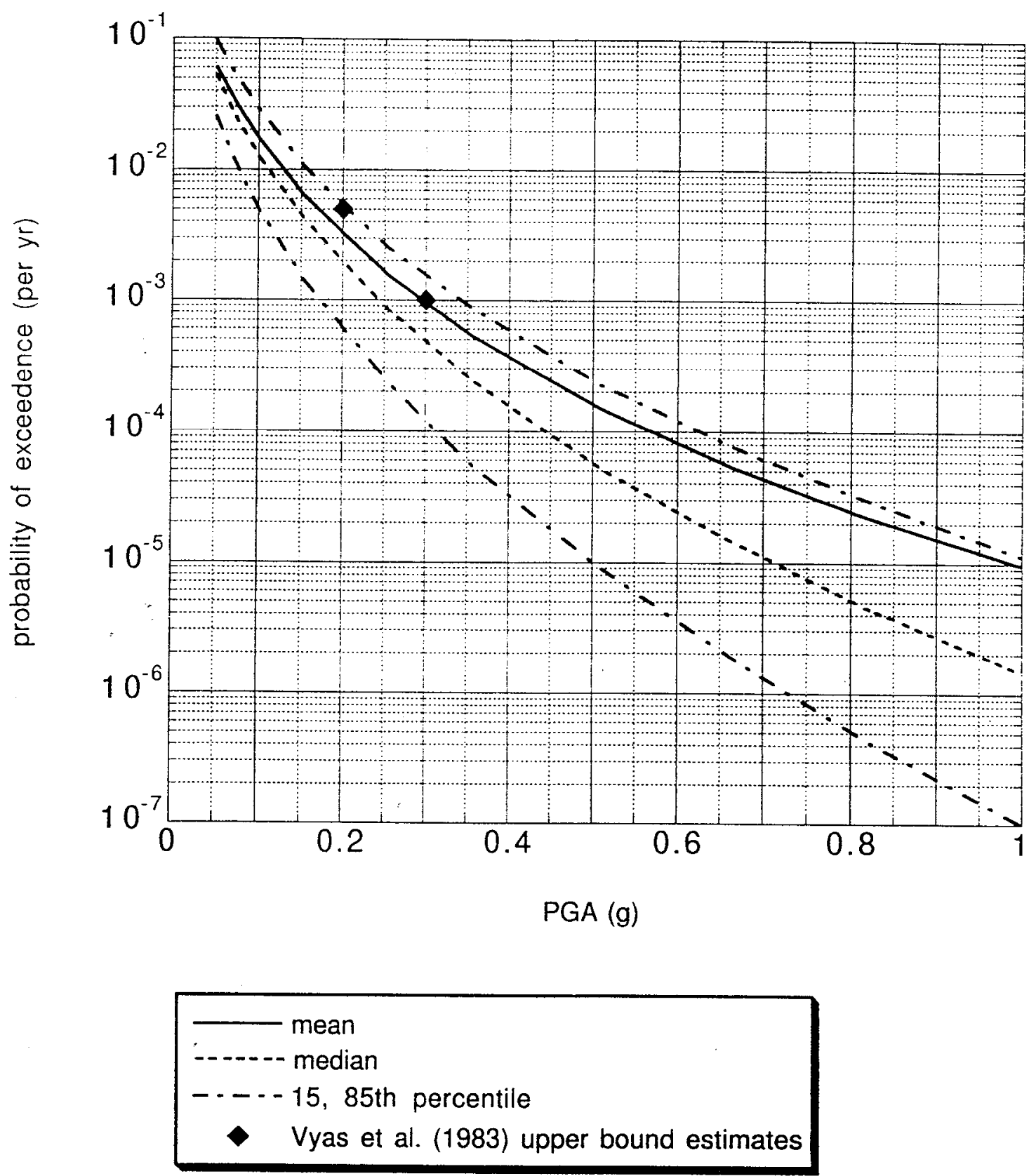


\section{APPENDIX}

\section{PARTICIPANTS IN THE PHASE 1 STANFORD WORKSHOP}

\section{August 16-17, 1995}

$\begin{array}{ll}\text { Norman Abrahamson } & \text { Consultant to LLNL } \\ \text { Larry Anderson } & \text { U.S. Bureau of Reclamation } \\ \text { Ralph Archuleta } & \text { University of California, Santa Barbara } \\ \text { Auguste Boissonnade } & \text { LLNL } \\ \text { Dave Boore } & \text { U.S. Geological Survey } \\ \text { Allin Cornell } & \text { Stanford University } \\ \text { Dan O'Connell } & \text { U.S. Bureau of Reclamation } \\ \text { Chris Cramer } & \text { California Div. Mines and Geology } \\ \text { C.B. Crouse } & \text { Dames and Moore } \\ \text { Martin Eskijian } & \text { California State Lands Commission } \\ \text { Bill Foxall } & \text { LLNL } \\ \text { Bruce Luyendyk } & \text { University of California, Santa Barbara } \\ \text { Gary Huftile } & \text { Oregon State University } \\ \text { Larry Hutchings } & \text { LLNL } \\ \text { Paul Mount } & \text { California State Lands Commission } \\ \text { Robert Murray } & \text { LLNL } \\ \text { Jean Savy } & \text { LLNL } \\ \text { Charles Smith } & \text { MMS } \\ \text { Christopher Sorlien } & \text { UC, Santa Barbara/Lamont-Doherty Earth Observatory } \\ \text { Cathy Stanek } & \text { MMS } \\ \text { John Stieg } & \text { Mobil Oil, Santa Barbara } \\ \text { Frank Victor } & \text { MMS } \\ \text { Steven Ward } & \text { University of California, Santa Cruz } \\ & \end{array}$

